\title{
SOURCES OF INNOVATION ACTIVITY AS A FACTOR OF ECONOMIC DEVELOPMENT
}

\author{
Olga BUCHINSKAIA (D), Elena STREMOUSOVA (iD) \\ Department of Economic Theory and Economic Policy, Graduate School of Economics and Management, \\ Ural Federal University, 19 Mira Street, 620002, Ekaterinburg, Russia \\ *E-mail: gto2000@list.ru
}

\begin{abstract}
Purpose - the purpose of the study is to define the sources and restrictions of new industry development based on the R\&D -related factors of the countries studied; to show the conditions of inequality based on the existing infrastructure, which are obstacles for achieving an advantage in technology.

Research methodology - the panel studies were conducted on four groups of countries divided by the level of GDP per capita. High technology exports and charges for the use of the intellectual property were used as dependent variables.

Findings - as a result of the study, the factors that influenced the dependent variables in each of these groups of countries were identified. The differences in the significance of factors are shown.

Research limitations - the limitations of the study are significant gaps in the time series for a number of countries. They make it impossible to use such data in the econometric model. Some indicators are taken into account relatively recently, which makes it impossible to consider long-term trends.

Practical implications - the results of the research should help the country decision-makers optimize measures to develop domestic $\mathrm{R} \& \mathrm{D}$ and innovative production.

Originality/Value - the originality of the research is the study of country sets grouped by the level of GDP per capita. The specifics of patents and trademarks influence on the innovative activity of countries with different income levels are determined.
\end{abstract}

Keywords: economic growth; intellectual property; high technology exports; research and development; trademarks; patents; technology spillovers.

JEL Classification: O14, O33.

Conference topic: Digitalization of Business Processes: Trends, Challenges, Solutions.

\section{Introduction}

Identifying the sources of economic growth and the causes of International inequality is one of the essential issues of the modern economy. The diversity in scientific and technological development and the use of its achievements are playing a significant role in economic divergence. The use of innovations and new technologies makes it possible to create goods and services on a large scale. An increasingly large part of the cost of these goods and services is created by high technologies while the share of manual labor is decreasing. In the production of innovative goods and services, a significant part of their value falls on patents and protected by international law. Many goods and services in the modern world contain elements of intellectual property protected by patents and trademarks registered. Some of them, for example, software, are, in essence, the manifestation of intellectual property, since costs of product development and protection prevail in their value, while the costs of copying and delivering such products to the final consumer tend to zero. It creates a profit surplus for the patent owners. This excess profit is preserved even if a company transfers an assembly of goods to countries with more cheap resources or sells a franchise. Most of the head offices of multinational companies are located in developed countries with the highest GDP values, and thus profits from high-tech goods are collected in developed countries. Developing countries have relatively few patents and trademarks of their own to accumulate royalties. Holding the assembly plants of transnational corporations allows such countries to receive income only in the form of payments for resources, which are much cheaper than in developed countries. Thus, the presence of innovative activity has a significant connection with the wealth of the country. 
The development of R\&D activities in the country is the key to creating high-technology products that can significantly increase domestic value added, but it is equally important to keep the patented results of research activities at the disposal of the country's economic agents. This moment is important enough for the economic growth because, in the developing countries, where conditions for encouraging innovative activity are not created, the sale of patents to economic agents of foreign countries is not uncommon. These agents later used such patents to create marketable and expensive products. Some researchers migrate abroad where they achieved substantially greater success, and the results of their intellectual activity are more in demand.

The purpose of the study is to define the sources and restrictions of new industry development based on the R\&D -related factors of the countries studied. Methods of panel data analysis, starting with the pooled OLS model and ending with a panel with random effects were used. This study identifies the impact of factors related to R\&D activity on the indicators that are components of economic growth. For those indicators, we took the high technology exports and charges for the use of intellectual property. The choice of these indicators as dependent variables is because the influence on R\&D activity on the economic development is indirect, providing not GDP growth as is, but the ability for a country to create goods and services, which allows increasing the country's income. Therefore, identifying the factors influencing the high technologies exports and intellectual property, we can discuss how their dynamics affect the welfare of the country.

\section{Previous research review}

In one of the first works on the influence of non-residents application of trademarks on the economy of less developed countries, Chudnovsky (1979) states that most of the benefits from this cooperation are owned by the country that controls the trademark, while the recipient country misses these benefits, which can be attributed to social costs. The paper proposed measures to reduce the negative impact of foreign trademarks on the economies of developing countries.

Kitch (1994) studying the impact of trademarks and patents on countries with different income levels, writes not only about the difference in technology needs between developed and developing countries but also notes that less developed countries pay proportionally smaller amounts for using patents than developed countries. Later, McCalman (2002) argued that developing countries suffer from moving toward high standards of intellectual property protection, and this means may also reduce world welfare. Thompson and Rushing (1999) on the example of an analysis of 55 countries for 1975-1990 found that, on the one hand, the developed countries with open markets use substantially greater efforts to protect intellectual property. Low-income countries have not developed a significant R\&D infrastructure and have not emphasized strong patent protection.

Hadjimanolis (1999) identifies a number of barriers that less developed countries face when adapting to new technologies. External barriers include access to technology, finance, and material resources. The internal ones involve problems of the human factor, difficulties with accounting, analysis and technology management, lack of financing within the country. Glass and Saggi (1998) offer a model of technology spillover through foreign direct investment from more developed countries to less developed ones and the progress of technologies in developing countries as an imitation of imported knowledge. However, these theories do not address the emergence of new knowledge and domestic patents in less developed countries.

However, the fate of knowledge created in countries is far from unambiguous. With the differences in the institutions of intellectual property protection, a reverse spillover is possible: intellectual capital owners migrate to regions where their knowledge is more applicable. D'Ambrosio et al. (2018) empirically found what qualified migrants play a role in opening up local innovation systems. This situation does not reduce but increase the technological and social gap between countries, slowing down the hope for convergence. The dynamics of change the impact of patents and trademarks on countries' economies in the process of globalization and after the adoption of the Agreement on Trade-Related Aspects of Intellectual Property Rights (TRIPS) is presented in Nam and Barnett (2011). They found that within the framework of the development of property rights, both according to patents and trademarks, "core" countries stand out, with the United States and Germany as the leaders. Other developed countries are significantly inferior to the leaders of the "core". Developing countries do not have the opportunity to develop or imitate innovations coming from developed countries. Developed countries involved in technology transfer import less technology from other developed countries. Baroncelli, Fink and Javorcik (2005) remark the uneven nature of the trademarks and patents transfer. In the realm of trademarks, most of them, including ones in less developed countries, belong to companies controlled by large industrialised countries. In patents, less than $5 \%$ of the total number of patients registered is performed by residents of developing countries in their own region. They also suggest that firms in developing countries make more profit from the initiation of trademarks than from the registration of domestic patents. Ismail and Fakir (2004) note the difficulties of intellectual property registration and protection for the developing countries' residents. The business of developed countries assign and register rights to these objects, thus creating trade barriers for entering the market to the firms from developing countries. Lall (2003) notes that in the short run, strengthening the protection of intellectual property through TRIPS may be less beneficial for developing countries, but in the long run, he expresses the hope that the positive impact of this agreement on their economies will 
increase. Filippetti and Archibugi (2015) believe that the uneven distribution of technological advances does not depend on intellectual property protection, but is due to the lack of developing countries' own investments in R\&D, education, and infrastructure.

Van Zeebroeck (2011) notes that in developed European countries, the life of a patent is increasing. A significant inflow of carriers of intellectual capital to countries with better conditions for the protection and use of patents is possible. Branstetter, Fisman and Fritz Foley (2006) take attention to the value of royalties paid by affiliates to parents for the sale or use of intangible property which captures technology licensing fees, and franchise fees, fees for the use of trademarks, and payments for other intangibles.

Sanchis et al. (2015) analyzed the impact of domestic patents, imported knowledge and human capital on total factor productivity for 50 years period for countries such as the United States, Great Britain, France, Germany and Spain. The results have shown a positive significance for the foreign intellectual capital inflow in all countries studied, but the impact of domestic patents on total factor productivity for Spain was negative. They explain this by the fact that it is easier for a relatively lagging economy to use foreign knowledge than to spend resources on its own R\&D activity. Dereli (2015) considers innovations to be a competitive advantage. She suggests that the administration should support new ideas and innovative tendencies to succeed. Similarly, Gogodze (2016) asserts that the country's political, regulatory, and business environment indirectly, but affects its innovation capabilities. Hence, developing countries should improve their institutions to increase their innovative capabilities.

In the survey of SME in the Slovak Republic, Machová, Huszárik, \& Šimonová (2016) distinguish low innovation potential, taxation, legislation and regulations as inhibitory factors of innovative activity. Jones \& Hooper (2017) notes that a lack of support by senior managers might be a barrier for innovations. Another problem for developing countries arises if costs of Intellectual property rights protection may outweigh its benefits (Peng et al., 2017).

Hafner (2008) argue that non-G7 OECD countries benefit more from foreign rather than domestic R\&D activities. At the same time, Kuzubov (2018) notes that the economies of middle- and low-income countries accomplish innovation much better than their current level of development predicts. Liu, Lu and Cheng (2018) found that the increase in foreign R\&D impairs the country's ability to create its own patents. Therefore, its dependence on foreign technology reduces the development opportunities of countries with lower incomes. Thus, we see the prerequisites that developed and developing countries have to react differently to the dynamics of the development of intellectual property.

$\mathrm{Xu}$ and Chiang (2005) found a trend that for developed countries their own technologies and patents are crucial. This trend is not supported in the middle- and low-income countries as foreign patents become a significant source of technology spillover for these groups of countries. Frishammar et al. (2018) explain three trends in business processes including a shift to open models of innovation. However, these changes are not conducive to the convergence of the economic gap. So, the openness of innovations is expressed primarily in the possibility of obtaining additional funding through foreign direct investments or crowdfunding systems, which provides resources for building useful models for small innovative businesses, but does not give authors of inventions patent protection for their products. Thus, it allows to create innovations, but it does not enable those innovations to develop into a large business. Large companies prefer a closed innovation strategy, as it was shown in Korea's example by Yun et al. (2018). Hintošováet al. (2018) in the study of foreign investment inflows Visegrad countries notes what expenditures on research and development determinant had a negative impact on FDI. Hájek and Stejskal (2018) admit what investments directed to internal cooperation extends the ability to create innovation. Moaniba, Su \& Lee (2018) note the positive relationship between the number of patents and GDP per capita. Based on these investigations, we attempted to estimate an impact caused by patents and trademarks on innovation indicators of countries studied.

\section{Methodology}

The study used the methods of correlation analysis, OLS, panel analysis with fixed and random effects. For the study, we used data from the World Bank for 21 years (from 1996 to 2016 inclusive). The entire set of countries was divided into 4 groups according to the level of per capita GDP as of the year 2016:

- Countries with super-high income: from 20000 \$ US and above;

- Countries with high income: 12000 - $19999 \$$ US;

- Upper-middle-income countries: 4000 - 11 999\$ US;

- Lower-middle-income countries: 1000 - 3999 \$ US.

This division was made from the assumption that developed and developing countries have different reactions to the actions of residents and non-residents. Developed countries, possessing the greatest financial capabilities and developed institutions for protecting property rights, are the center of attraction for innovations, both domestic and foreign. As economic development decreases, the country is less and less dependent on its own innovations. Lowermiddle-income countries often have poor industrialization and a few of their own patents and trademarks. For countries with an income of less than \$ 3999 US, were not possible to conduct a study due to the lack of statistics for most countries. 
The following indicators were taken as variables for the study:

- Patent applications, nonresidents;

- Patent applications, residents;

- Scientific and technical journal articles;

- Researchers in R\&D (per million people);

- Trademark applications, direct nonresident;

- Trademark applications, direct resident.

We chose indicators of patent and trademark applications by residents and non-residents because they allow to figure out the difference in the internal and external activity of economic entities. Scientific and technical journal articles and Researchers in R\&D were selected to assess their own innovative potential of the groups of countries.

There are two dependable indicators were chosen for the analysis: the high technology exports and charges for the use of intellectual property. High-technology exports include exports of goods with high R\&D intensity, such as in electronics, computers, pharmaceuticals, aerospace products. These products have a high share of value added and affect economic growth (Kabaklarli, Duran, \& Üçler, 2018). Charges for the use of intellectual property are payments between residents and nonresidents for the legitimate use of patents, trademarks, copyrights, industrial processes and designs including trade secrets, and franchises. Sattar \& Mahmood (2011) reveal that intellectual property has a positive impact on economic growth.

Before the beginning of the econometric analysis, a correlation analysis of the variables was carried out to avoid multicollinearity. After that, for each dependent variable for each group of countries, three types of panel analysis (pooled OLS, fixed effects and random effects panel) were conducted. We associate the need for three types of regression analysis with the heterogeneity of the countries studied according to their industrial development. The difference is particularly observed in the group of countries with super-high incomes, where there are industrial leaders with high volumes of exports of high-tech products (Japan, France, Korea, Singapore, United States, Germany) and countries and countries with lesser volumes of this type of exports. There is also significant diversity in the group of countries with low average incomes, in which there are both countries with the developed industry and predominantly agrarian states.

\section{Results and discussion}

Initially, we suggested that six variables should have a significant impact on high technology exports and charges for the use of intellectual property. However, the number of explanatory variables was reduced during the study. After the correlation analysis, it was revealed that the Scientific and technical journal articles have a strong correlation with patent applications by residents variable. In addition, in many countries studied, this indicator has been calculated since 2003, which made it possible to abandon this indicator in favor of Patent applications, residents variable.

We analyzed the remaining variables using the least squares method, a fixed effects panel model and a random effects panel model. In the group of countries with super high income, we examined 16 countries for 21 years. The model for this group of countries and for the group of countries with high incomes, showed heteroscedasticity, the source of which was Researchers in R\&D variable. This heteroscedasticity was present both in the influence's assessment of variables on the export of high technologies and on charges for the use of intellectual property.

After excluding this indicator from the analysis, the model got significant results presented in Table 1. For patents applied by residents, USA, Japan and South Korea showed the highest results. The second-in-hand group includes Germany, France, UK. The rest of the countries show relatively similar results but show a relatively small change. According to Trademark applications and Patent applications filed by non-residents, the United States leads, the rest of the countries are much behind. Patent and Trademark applications have a multidirectional trend in different groups of countries. If in the USA, Australia, Korea, Singapore there is a trend towards an increase in Trademark applications, direct nonresident, in the UK, Spain, Italy, Germany, France, Belgium, Austria, the quantitative values of this indicator decrease. In terms of patents registered by nonresidents, the USA, Australia, Germany, Japan, South Korea, and Singapore have an increasing trend. The downward trend of this indicator is observed in Austria, Belgium, Finland, France, Norway, Spain, Switzerland.

According to Breush-Pagan and Hausman tests, a model random effects model was recognized as optimal. In Table 1 and farther, the optimal calculation method is highlighted by the shaded area. In parentheses, the psignificance is represented.

By the results of calculation Trademark applications, direct resident was statistically insignificant. The remaining significant indicators show that applications for patents made by residents have a positive impact on exports of high-tech products, while the actions of non-residents, both in terms of Patent applications and Trademark applications, lead to a decrease in this indicator. This is an expected outcome since foreign trademarks with a good reputation are rivals to domestic ones. Part of the profits from the use of patents and trademarks of non-residents goes abroad to trademark owners. In terms of Between and Within estimators it can be seen that the performance of countries with super high incomes significantly differs from each other. 
Table 1. Influence of the variables studied on the logarithm of the high technology exports in super high-income countries (calculated by authors source: World Bank (2019))

\begin{tabular}{|c|c|c|c|c|c|c|c|}
\hline Variable/Model & $\begin{array}{c}\text { Patent appli- } \\
\text { cations, non- } \\
\text { residents, } \\
\text { Log }\end{array}$ & $\begin{array}{c}\text { Patent applica- } \\
\text { tions, residents, } \\
\text { Log }\end{array}$ & $\begin{array}{c}\text { Trademark ap- } \\
\text { plications, direct } \\
\text { nonresident, } \\
\text { Log }\end{array}$ & $\begin{array}{c}\text { Trademark appli- } \\
\text { cations, direct } \\
\text { resident, Log }\end{array}$ & Between & Within & $\mathrm{R}^{2}$ \\
\hline OLS & - & $\begin{array}{c}0.441602 \\
(1.78 \mathrm{e}-29)\end{array}$ & - & $(0.0716407)$ & - & - & 0.499027 \\
\hline $\begin{array}{c}\text { Fixed Effects } \\
\text { Panel }\end{array}$ & $\begin{array}{c}-0.20609 \\
(1.41 \mathrm{e}-05)\end{array}$ & $\begin{array}{c}0.933104 \\
(4.92 \mathrm{e}-28)\end{array}$ & $\begin{array}{c}-0.236600 \\
(8.43 \mathrm{e}-08)\end{array}$ & - & - & - & 0.962951 \\
\hline $\begin{array}{c}\text { Random Effects } \\
\text { Panel }\end{array}$ & -0.194307 & $\begin{array}{c}0.871568 \\
(1.91 \mathrm{e}-05)\end{array}$ & $\begin{array}{c}-0.231421 \\
(8.06 \mathrm{e}-36)\end{array}$ & - & 1.10051 & 0.0727019 & - \\
\hline
\end{tabular}

Table 2. Evaluation of the impact of the variables studied on the logarithm of the charges for the use of intellectual property (calculated by authors source: World Bank (2019))

\begin{tabular}{|c|c|c|c|c|c|c|c|}
\hline Variable/Model & $\begin{array}{c}\text { Patent appli- } \\
\text { cations, non- } \\
\text { residents, } \\
\text { Log }\end{array}$ & $\begin{array}{c}\text { Patent applica- } \\
\text { tions, residents, } \\
\text { Log }\end{array}$ & $\begin{array}{c}\text { Trademark ap- } \\
\text { plications, direct } \\
\text { nonresident, } \\
\text { Log }\end{array}$ & $\begin{array}{c}\text { Trademark appli- } \\
\text { cations, direct } \\
\text { resident, Log }\end{array}$ & Between & Within & $\mathrm{R}^{2}$ \\
\hline OLS & $\begin{array}{c}0.1426149 \\
(3.09 \mathrm{e}-05)\end{array}$ & $\begin{array}{c}0.222943 \\
(4.40 \mathrm{e}-08)\end{array}$ & - & $0.103849(0.0040)$ & - & - & 0.522839 \\
\hline $\begin{array}{c}\text { Fixed Effects } \\
\text { Panel }\end{array}$ & $\begin{array}{c}-0.224200 \\
(0.0009)\end{array}$ & $\begin{array}{c}1.21950(2.58 \mathrm{e}- \\
23)\end{array}$ & $\begin{array}{c}-0.588019 \\
(4.61 \mathrm{e}-15)\end{array}$ & $\begin{array}{c}0.0436054 \\
(0.0542)\end{array}$ & - & - & 0.914336 \\
\hline $\begin{array}{c}\text { Random Effects } \\
\text { Panel }\end{array}$ & $\begin{array}{c}-0.151768 \\
(0.0168)\end{array}$ & $\begin{array}{c}0.887597 \\
(2.88 \mathrm{e}-23)\end{array}$ & $\begin{array}{c}-0.533512 \\
(2.28 \mathrm{e}-13)\end{array}$ & $\begin{array}{c}0.0532248 \\
(0.0225)\end{array}$ & 0.605591 & 0.130955 & - \\
\hline
\end{tabular}

Since the income from the use of intellectual property exceeds the revenue from the export of high-tech products for developed countries, the influence of regressors on the Charges for the use of intellectual property should have a greater effect. We justified this assumption because of a panel study presented in Table 2 . Here, the tests showed the optimality of the evaluation using the fixed effects model. All four variables studied were considered significant. Again, the positive dependence of indicators related to the activities of residents and the negative impact for indicators relating to nonresidents on the response variable is seen. The variation between countries was significantly lower, which is due to more equal opportunities for information tradings than high-tech products exports. The fact that the collection and export of high-tech goods can be carried out at assembly plants of other countries than the patent or trademark owner country can explain this difference.

In the group of high-income countries, we investigated 12 countries. From the group on the indicators of the patent residents' activity, the leading countries are Argentina, Czech Republic, Portugal. In terms of patents registered by non-residents, Argentina and Chile steadily lead. Particular attention should be paid to the dynamics of this indicator in the Czech Republic and Hungary, where it grew until the beginning of the 2000s, and then dropped, reaching 47 in 2016 against 5031 in 2002 in the Czech Republic and 49 against 5064 in 2002 in Hungary. We present the results of the impact of these indicators in this group of countries on high-tech product exports in Table 3.

In the results of regression for this group of countries, the negative effect on the resultant variable from the factors related to the non-residents activities is clearly seen. The factors related to residents showed statistical insignificance.

The value of the Between estimator is significantly higher than for the first group of countries since the difference in their high-tech production levels is expressed more clearly in these countries. Obviously, there is a flow of non-residents to countries with more pleasant economic conditions in creating assembly facilities by multinational corporations in countries of this group.

The influence of the variables studied on Charges for the use of intellectual property in Table 4 showed greater inclusiveness of variables in the model. Only Trademark applications, direct resident was statistically insignificant. The tendency of the positive influence of the residents' activity and the negative influence of the non-residents' actions on the resulting variable is noticeable. The significance of the Between estimator is similar to that of countries with a super high-income-level, and the Within indicator is higher than in the previous group. This can be explained because while in the super high-income group, charges for the use of intellectual property in all countries except the US grew at a moderate pace, the countries in the high-income group experienced a sharp increase in this indicator since 2003, with Hungary, Argentina, Chile and Czech has shown a sharp increase. 
Table 3. Impact of the variables studied on the logarithm of high technology exports in high-income countries (calculated by authors source: World Bank (2019))

\begin{tabular}{|c|c|c|c|c|c|c|c|}
\hline Variable/Model & $\begin{array}{l}\text { Patent appli- } \\
\text { cations, non- } \\
\text { residents, } \\
\text { Log }\end{array}$ & $\begin{array}{l}\text { Patent applica- } \\
\text { tions, residents, } \\
\text { Log }\end{array}$ & $\begin{array}{c}\text { Trademark ap- } \\
\text { plications, direct } \\
\text { nonresident, } \\
\text { Log }\end{array}$ & $\begin{array}{l}\text { Trademark appli- } \\
\text { cations, direct } \\
\text { resident, Log }\end{array}$ & Between & Within & $\mathrm{R}^{2}$ \\
\hline OLS & - & 0.927068 & $\begin{array}{l}-1.14158 \\
(1.56 \mathrm{e}-28)\end{array}$ & $\begin{array}{l}0.167981 \\
(0.0088)\end{array}$ & - & - & 0.495738 \\
\hline $\begin{array}{c}\text { Fixed Effects } \\
\text { Panel }\end{array}$ & $\begin{array}{l}-0.273904 \\
(1.64 \mathrm{e}-08)\end{array}$ & - & $\begin{array}{l}-0.585334 \\
(3.02 \mathrm{e}-06)\end{array}$ & - & - & - & 0.844289 \\
\hline $\begin{array}{c}\text { Random Effects } \\
\text { Panel }\end{array}$ & $\begin{array}{l}-0.266201 \\
(1.25 \mathrm{e}-08)\end{array}$ & - & $\begin{array}{l}-0.586322 \\
(1.69 \mathrm{e}-06)\end{array}$ & - & 2.53993 & 0.448826 & - \\
\hline
\end{tabular}

Table 4. The effect of the variables studied on the logarithm of charges for the use of intellectual property in high-income countries (calculated by authors source: World Bank (2019))

\begin{tabular}{|c|c|c|c|c|c|c|c|}
\hline Variable/Model & $\begin{array}{c}\text { Patent appli- } \\
\text { cations, non- } \\
\text { residents, } \\
\text { Log }\end{array}$ & $\begin{array}{c}\text { Patent applica- } \\
\text { tions, residents, } \\
\text { Log }\end{array}$ & $\begin{array}{c}\text { Trademark ap- } \\
\text { plications, di- } \\
\text { rect nonresi- } \\
\text { dent, Log }\end{array}$ & $\begin{array}{c}\text { Trademark appli- } \\
\text { cations, direct } \\
\text { resident, Log }\end{array}$ & Between & Within & $\mathrm{R}^{2}$ \\
\hline OLS & - & $\begin{array}{c}0.865713 \\
(3.75 \mathrm{e}-22)\end{array}$ & $\begin{array}{c}-0.444776 \\
(0.0013)\end{array}$ & $\begin{array}{c}0.498378 \\
(9.77 \mathrm{e}-10)\end{array}$ & - & - & 0.647246 \\
\hline $\begin{array}{c}\text { Fixed Effects } \\
\text { Panel }\end{array}$ & -0.354278 & $\begin{array}{c}0.204078 \\
(6.85 \mathrm{e}-14)\end{array}$ & $\begin{array}{c}-0.387880 \\
(0.0681)\end{array}$ & - & - & - & 0.879089 \\
\hline $\begin{array}{c}\text { Random Effects } \\
\text { Panel }\end{array}$ & -0.299582 & $\begin{array}{c}0.471917 \\
(1.75 \mathrm{e}-09)\end{array}$ & $\begin{array}{c}(1.53 \mathrm{e}-05) \\
-0.368379\end{array}$ & 0.0918895 & 0.611799 & 0.394157 & - \\
\hline
\end{tabular}

Table 5. Influence of the variables studied on the logarithm of the export of new technologies in countries with upper-middle income levels (calculated by authors source: World Bank (2019))

\begin{tabular}{|c|c|c|c|c|c|c|c|}
\hline Variable/Model & $\begin{array}{c}\text { Patent appli- } \\
\text { cations, non- } \\
\text { residents, } \\
\text { Log }\end{array}$ & $\begin{array}{c}\text { Patent applica- } \\
\text { tions, residents, } \\
\text { Log }\end{array}$ & $\begin{array}{c}\text { Trademark ap- } \\
\text { plications, di- } \\
\text { rect nonresi- } \\
\text { dent, Log }\end{array}$ & $\begin{array}{c}\text { Trademark appli- } \\
\text { cations, direct } \\
\text { resident, Log }\end{array}$ & Between & Within & $\mathrm{R}^{2}$ \\
\hline OLS & - & $\begin{array}{c}0.398178 \\
(4.55 \mathrm{e}-10)\end{array}$ & $\begin{array}{c}1.43910 \\
(2.83 \mathrm{e}-08)\end{array}$ & $\begin{array}{c}0.290172 \\
(0.0392)\end{array}$ & - & - & 0.618617 \\
\hline $\begin{array}{c}\text { Fixed Effects } \\
\text { Panel }\end{array}$ & -0.218350 & - & $\begin{array}{c}-0.599152 \\
(8.38 \mathrm{e}-07)\end{array}$ & $\begin{array}{c}1.20427 \\
(3.37 \mathrm{e}-31)\end{array}$ & - & - & 0.972453 \\
\hline $\begin{array}{c}\text { Random Effects } \\
\text { Panel }\end{array}$ & -0.200214 & - & -0.583472 & 1.23320 & 2.69646 & 0.218414 & - \\
\hline
\end{tabular}

In the group of countries with an upper-middle income level, we studied 14 countries. We excluded China from this group since the growth rates of the indicators were much higher than the growth rates of the other countries of the group. Of the remaining countries, in terms of patents registered to non-residents, as well as trademark applications by direct nonresidents, we observe a decrease only in Bulgaria and Romania. In the rest of the countries, those factors are of increase or stable. For Patents and trademarks, registered by residents, all the countries studied have a stable or increasing trend. We present the results of the analysis of the impact of variables studied on the hightechnology exports in Table 5. The correlation analysis has shown what the variables Scientific and technical journal articles and Researchers in R\&D have a strong correlation with Patent applications by residents. Since the last variable contains more data, it was decided to use it in the study. 
In the group of upper-middle-income countries, there is again a negative dependence on the number of trademarks registered by non-residents and a positive connection on the ones applied by residents. The number of patents registered by non-residents turned out to be statistically insignificant. This group of countries, like the previous one, differs in quantity of foreign production assembly facilities, which causes a difference in the export of high-tech goods.

In the analysis of the variables studied the impact on charges for the use of intellectual property (Table 6), all four indicators were considered significant. A feature of this result is the significantly greater value of the positive influence of trademarks registered by residents compared to other groups of countries. The second aspect is the positive impact of trademarks registered by non-residents. It is assumed that this positive impact is due to the accumulation of knowledge by countries through learning by doing. The distribution of a foreign trademark's assembly units in the country allows domestic economic agents to gain access to a number of technologies and, consequently, to establish their own production of similar products under their own trademarks. China is a well-known example of this approach, but this is also true of other countries in the Asia-Pacific region, which have made a qualitative leap in the creation of high-tech goods and services, in particular, Thailand and Malaysia. The value of the Within estimator, the maximum among all four groups of countries, also shows a qualitative leap. Another characteristic feature is the appearance of the negative impact of patents registered by residents. The authors suggest that this situation has developed because of an insufficiently developed patents adopting system. A resident who has registered a patent may be more interested in selling it to foreign business. If this phenomenon becomes widespread, the "leakage" of patents leads to an inverse dependence of fees for the use of intellectual property on the number of patents.

Table 6. The effect of the variables studied on the logarithm of charges for the use of intellectual property in countries with upper-middle income (calculated by authors source: World Bank (2019))

\begin{tabular}{|c|c|c|c|c|c|c|c|}
\hline Variable/Model & $\begin{array}{c}\text { Patent appli- } \\
\text { cations, non- } \\
\text { residents, Log }\end{array}$ & $\begin{array}{c}\text { Patent applica- } \\
\text { tions, residents, } \\
\text { Log }\end{array}$ & $\begin{array}{c}\text { Trademark ap- } \\
\text { plications, direct } \\
\text { nonresident, } \\
\text { Log }\end{array}$ & $\begin{array}{c}\text { Trademark appli- } \\
\text { cations, direct } \\
\text { resident, Log }\end{array}$ & Between & Within & $\mathrm{R}^{2}$ \\
\hline OLS & - & - & $\begin{array}{c}0.524309 \\
(0.0032)\end{array}$ & $\begin{array}{c}0.710936 \\
(2.63 \mathrm{e}-11)\end{array}$ & - & - & 0.529582 \\
\hline $\begin{array}{c}\text { Fixed Effects } \\
\text { Panel }\end{array}$ & $\begin{array}{c}-0.34291(0.0 \\
002)\end{array}$ & $\begin{array}{c}-0.310994 \\
(0.0237)\end{array}$ & $\begin{array}{c}0.503720 \\
(0.0331)\end{array}$ & $\begin{array}{c}1.67594 \\
(5.96 \mathrm{e}-14)\end{array}$ & - & - & 0.776506 \\
\hline $\begin{array}{c}\text { Random Effects } \\
\text { Panel }\end{array}$ & $\begin{array}{c}-0.329479 \\
(2.47 \mathrm{e}-05)\end{array}$ & - & $\begin{array}{c}0.508177 \\
(0.0248)\end{array}$ & $\begin{array}{c}1.23750 \\
(1.57 \mathrm{e}-17)\end{array}$ & 0.755395 & 0.809027 & - \\
\hline
\end{tabular}

In the group of lower-middle-income countries, we analyzed 11 countries. India was excluded from the countries studied as this country like China showed uncharacteristic growth rates of the variables studied for this group of countries. This group is marked by a rather poor patent activity. So, in terms of patents applied by residents, most countries have growth, but at a low pace, a trend, quantitatively limited to two to three-digit numbers, except for Ukraine, which shows a steady downward trend since 2001, when this number dropped from 7208 to 22 in 2016. Georgia, Moldova and Guatemala are also showing a decline. The number of patents registered by nonresidents in these countries exceeds the results of residents and has an uptrend in most countries. Only Moldova and Pakistan have a slight decrease in foreign patents applied. All countries studied, except Indonesia, show an increase in trademarks registered by non-residents, while all countries show an increase in their own trademarks. The results of the regression analysis of the impact of these variables on the export of high-tech products are presented in Table 7.

Table 7. Impact of the variables under study on the logarithm of the export of new technologies in countries with a lower-middle income level (calculated by authors source: World Bank (2019))

\begin{tabular}{|c|c|c|c|c|c|c|c|}
\hline Variable/Model & $\begin{array}{c}\text { Patent appli- } \\
\text { cations, non- } \\
\text { residents, } \\
\text { Log }\end{array}$ & $\begin{array}{c}\text { Patent applica- } \\
\text { tions, residents, } \\
\text { Log }\end{array}$ & $\begin{array}{c}\text { Trademark ap- } \\
\text { plications, direct } \\
\text { nonresident, } \\
\text { Log }\end{array}$ & $\begin{array}{c}\text { Trademark appli- } \\
\text { cations, direct } \\
\text { resident, Log }\end{array}$ & Between & Within & $\mathrm{R}^{2}$ \\
\hline OLS & $\begin{array}{c}0.794152 \\
(5.68 \mathrm{e}-14)\end{array}$ & - & $\begin{array}{c}1.63774(4.66 \mathrm{e}- \\
10)\end{array}$ & - & - & - & 0.590864 \\
\hline Fixed Effects & $\begin{array}{c}0.491576 \\
\text { Panel }\end{array}$ & $\begin{array}{c}0.378300 \\
(0.0003)\end{array}$ & $\begin{array}{c}0.813458 \\
(0.0007)\end{array}$ & $\begin{array}{c}0.827240(9.02 \mathrm{e}- \\
09)\end{array}$ & - & - & 0.913000 \\
\hline $\begin{array}{c}\text { Random Effects } \\
\text { Panel }\end{array}$ & $\begin{array}{c}0.488268 \\
(0.0001)\end{array}$ & $\begin{array}{c}0.358286 \\
(0.0008)\end{array}$ & $\begin{array}{c}0.828462 \\
(0.0002)\end{array}$ & $\begin{array}{c}0.808581(1.61 \mathrm{e}- \\
09)\end{array}$ & 3.24299 & 0.687128 & \\
\hline
\end{tabular}


According to the Pagan and Hausman test results, a panel with random effects showed the optimality of evaluation. All four parameters, in this case, have a positive impact on the of high-technology exports. We can explain the positive impact of non-resident patents on the resulting variable that a significant part of the countries' exports is made under license and with the help of non-resident intellectual property. It can also explain the positive sign of the impact of non-resident trademark applied variable. The high value of the Between estimator shows a significant difference between the countries in this group. In some of them, the industry is well-developed others are primarily agrarian. The impact of the variables studied on the charges for the use of intellectual property in the group of lowermiddle-income countries is presented in Table 8.

Table 8 The effect of the variables studied on the logarithm of deductions for the use of intellectual property in countries with a lower-middle-income level.(calculated by authors source: World Bank (2019))

\begin{tabular}{|c|c|c|c|c|c|c|c|}
\hline Variable/Model & $\begin{array}{c}\text { Patent appli- } \\
\text { cations, non- } \\
\text { residents, Log }\end{array}$ & $\begin{array}{c}\text { Patent applica- } \\
\text { tions, residents, } \\
\text { Log }\end{array}$ & $\begin{array}{c}\text { Trademark ap- } \\
\text { plications, direct } \\
\text { nonresident, } \\
\text { Log }\end{array}$ & $\begin{array}{c}\text { Trademark ap- } \\
\text { plications, direct } \\
\text { resident, Log }\end{array}$ & Between & Within & $\mathrm{R}^{2}$ \\
\hline OLS & $\begin{array}{c}0.406841 \\
(1.82 \mathrm{e}-13)\end{array}$ & - & $\begin{array}{c}1.42149(2.75 \mathrm{e}- \\
24)\end{array}$ & $\begin{array}{c}0.527179(3.55 \mathrm{e}- \\
13)\end{array}$ & - & - & 0.885321 \\
$\begin{array}{c}\text { Fixed Effects } \\
\text { Panel }\end{array}$ & - & -0.198235 & $\begin{array}{c}0.573038 \\
(0.0020)\end{array}$ & $\begin{array}{c}0.969161(3.93 \mathrm{e}- \\
12)\end{array}$ & - & - & 0.918038 \\
\hline $\begin{array}{c}\text { Random Effects } \\
\text { Panel }\end{array}$ & $\begin{array}{c}0.355311 \\
(3.26 \mathrm{e}-08)\end{array}$ & - & $\begin{array}{c}1.14471(4.98 \mathrm{e}- \\
15)\end{array}$ & $\begin{array}{c}0.659839(8.14 \mathrm{e}- \\
15)\end{array}$ & 0.0306812 & 0.391796 & - \\
\hline
\end{tabular}

Patent applications by non-residents showed a statistically insignificant result. In this group of countries, there are also no developed institutions to support and stimulate intellectual property. Therefore, it is more profitable for an innovator to sell a patent abroad. It can explain the inverse dependence of Charges for the use of intellectual property dependable from the patents applied by non-residents factor. The dependence of the resultant variable on trademarks applied is positive both for residents and non-residents. We assume that the explanation for this is the same as for the upper-middle-income group of countries: through learning by doing. This situation is even more pronounced than in the group of countries with upper-middle-income levels: the positive impact of resident brands on the resulting variable is less than in countries of the third group, and non-residents - more than in the same group. The value of the Between estimator is the smallest among the groups of countries studied, which shows the small difference in the influence of variables on charges for the use of intellectual property.

\section{Limitations}

This study has several significant limitations for its recognition as an accurate model for assessing the influence of factors of innovation activity on economies. One of the most obvious restrictions is the lack of sufficient statistics for most of the countries. If for high-income countries we can find information, for middle- and low-income ones there are very few data. Even in developed countries, it is difficult to find sufficient volumes of statistical data for research. In particular, the factor $R \& D$ expenditure in business enterprises could have a significant impact on the variables studied, but there is limited information on it. It would be useful to include research such factors as Availability of latest technologies, Company spending on Research \& Development, FDI and technology transfer, but for these indicators, statistics have been conducted only since 2007. In terms of Firm-level technology absorption indicator, statistics are presented only since 2012. Within the data accumulation over time, this problem can be solved. It would also be useful to include indexes to estimate the Copyright protection in a country and the Time to register a patent. The next limitation is the impossibility of separating intellectual property objects having a commodity nature from cultural objects: film production, publishing, gaming, a low-tech franchise in the service sector.

\section{Conclusions}

The study revealed an ambiguous reaction of the high technology exports and charges for the use of intellectual property from the number of patents and trademarks registered by residents and non-residents of the countries. The results showed that countries with different levels of income per capita react to patents and trademarks created by non-residents differently.

For super-high and high-income countries, the activities of non-residents have a purely negative impact both towards high-tech exports and charges for the use of intellectual property. In these two groups of countries, the negative impact of non-residents' trademark registration exceeds the negative impact of non-residents' patent applica- 
tions. Since the magnitude of the coefficients relating to the activities of non-residents in the countries of the first group is lower than in the second one, countries with super-high income suffer from the abundance of non-residents trademarks and patents less than countries with high income. These results are true both in terms of the hightechnology exports and charges for the use of intellectual property. For charges for the use of intellectual property dependable indicator in the countries with a super-high income level, the impact of patents registered by residents far exceeds the influence of domestic trademarks.

Because of the statistically insignificant domestic trademark factor in the tables $1,3-4$, it is impossible to assess the impact of this factor on the export of high-tech products and the difference in the significance of this factor in countries with high and super-high-income levels in this study.

The lower the income level in countries, the higher the positive impact of the residents' innovation activity. Developing countries gain a large part of their income from these types of activities because of the activities of nonresidents. The lower the income level of the country, the more the activity of non-residents suppresses the residents' one and leads to crowding out their own domestic patent activity. In this regard, developing countries need to take measures, primarily to stimulate their own brands, to create favorable conditions for the innovative activity of their own researches: to encourage innovative activity, to create institutions for domestic innovations adopting. However, in some developing countries, like India and China, the trends might be different due to their high inclusion in world markets. For such type of countries, an additional analysis should be made. Further research anticipates an in-depth study of the countries within the selected groups with the inclusion in the analysis of factors reflecting the level of development of the infrastructure of innovation activities of the institutions of foreign technologies adoption, registration and protection of intellectual property rights.

\section{References}

Baroncelli, E., Fink, C., \& Javorcik, B. S. (2005). The global distribution of trademarks: Some stylised facts. World Economy, 28(6), 765-782. https://doi.org/10.1111/j.1467-9701.2005.00706.x

Branstetter, L. G., Fisman, R., \& Fritz Foley, C. (2006). Do stronger intellectual property rights increase international technology transfer? Empirical evidence from U. S. firm-level panel data. Quarterly Journal of Economics, 121(1), 321-349. https://doi.org/10.1093/qje/121.1.321

Chudnovsky, D. (1979). Foreign trademarks in developing countries. World Development, 7(7), 663-682. https://doi.org/10.1016/0305-750X(79)90080-9

D’Ambrosio, A., Montresor, S., Parrilli, M. D., \& Quatraro, F. (2018). Migration, communities on the move and international innovation networks: An empirical analysis of Spanish regions. Regional Studies, 53(1), 6-16. https://doi.org/10.1080/00343404.2018.1426850

Dereli, D. D. (2015). Innovation Management in Global Competition and Competitive Advantage. Procedia - Social and Behavioral Sciences. 195, 1365-1370. https://doi.org/10.1016/j.sbspro.2015.06.323

Filippetti, A., \& Archibugi, D. (2015). The Globalization of Intellectual Property Rights. The Global Handbook of Science, Technology and Innovation. Oxford: Wiley. https://doi.org/10.1002/9781118739044

Frishammar, J., Richtnér, A., Brattström, A., Magnusson, M., \& Björk, J. (2018). Opportunities and challenges in the new innovation landscape: Implications for innovation auditing and innovation management. European Management Journal. 1-14. https://doi.org/10.1016/j.emj.2018.05.002

Glass, A. J., \& Saggi, K. (1998). International technology transfer and the technology gap. Journal of Development Economics, 55(2), 369-398. https://doi.org/10.1016/S0304-3878(98)00041-8

Gogodze, J. (2016). Mechanisms and Functions within a National Innovation System. Journal of technology management \& innovation, 11(4), 12-21. https://dx.doi.org/10.4067/S0718-27242016000400003

Hadjimanolis, A. (1999). Barriers to innovation for SMEs in a small less developed country (Cyprus). Technovation, 19(9), 561570. https://doi.org/10.1016/S0166-4972(99)00034-6

Hafner K. A. (2008). The pattern of international patenting and technology diffusion. Applied Economics, 40(21), $2819-2837$. https://doi.org/10.1080/00036840600981630

Hájek, P., \& Stejskal, J. (2018). R\&D Cooperation and Knowledge Spillover Effects for Sustainable Business Innovation in the Chemical Industry. Sustainability, 10(4), 1064. https://doi.org/10.3390/su10041064

Hintošová, A. B., Bruothová, M., Kubíková, Z., \& Ručinský, R. (2018). Determinants of foreign direct investment inflows: A case of the Visegrad countries. Journal of International Studies, 11(2), 222-235.

https://doi.org/10.14254/2071-8330.2018/11-2/15

Ismail, Z., \& Fakir, T. (2004). Trademarks or trade barriers?: Indigenous knowledge and the flaws in the global IPR system. International Journal of Social Economics. https://doi.org/10.1108/03068290410515493

Jones, S., Hooper, T. (2017). New Zealand's ICT Strategy: The Respective Roles of Senior and Middle Management in Promoting Collaboration and Innovation. Asia \& the Pacific Policy Studies, 4(3), 484-495. https://doi.org/10.1002/app5.199

Kabaklarli, E., Duran, M. S., \& Üçler, Y. T. (2018). High-technology exports and economic growth: Panel data analysis for selected OECD countries. Forum Scientiae Oeconomia, 6(2), 47-60. https://doi.org/10.23762/FSO_VOL6NO2_18_4

Kitch, E. W. (1994). The patent policy of developing countries. Pacific Basin Law Journal, 13(1), 166-178. Retrieved from https://escholarship.org/uc/item/2w467909 
Kuzubov, A. A. (2018). The Transformation of Technological and Innovation Gap of Global Economy. The Azimuth Of Scientific Research: Economics And Management, 2(23), 191-195. Retrieved from https://cyberleninka.ru/article/n/transformatsiyatehnologicheskogo-i-innovatsionnogo-razryva-globalnoy-ekonomiki

Lall, S. (2003). Indicators of the relative importance of IPRs in developing countries. Research Policy, 32(9), 1657-1680. https://doi.org/10.1016/S0048-7333(03)00046-5

Liu, J., Lu, K., \& Cheng, S. (2018). International R\&D Spillovers and Innovation Efficiency. Sustainability, 10(11), 1-23. https://doi.org/10.3390/su10113974

Machová, R., Huszárik, E. S., \& Šimonová, M. (2016). Selected aspects of innovation policy for small and medium-sized enterprises. Journal of International Studies, 9(2), 219-232. https://doi.org/10.14254/2071-8330.2016/9-2/17

McCalman, P. (2002). National patents, innovation and international agreements. Journal of International Trade and Economic Development, 11(1), 1-14. https://doi.org/10.1080/09638190110093136

Moaniba, I. M., Su, H.-N., \& Lee, P.-C. (2018). Does reverse causality explains the relationship between economic performance and technological diversity?. Technological and Economic Development of Economy, 24(3), 859-892. https://doi.org/10.3846/tede.2018.1429

Nam, Y., \& Barnett, G. A. (2011). Globalization of technology: a Network analysis of global patents and trademarks. Technological Forecasting and Social Change, 78(8), 1471-1485. https://doi.org/10.1016/j.techfore.2011.06.005

Peng, M., Ahlstrom, D., Carraher, S., \& Shi, W. (2017). History and the Debate Over Intellectual Property. Management and Organization Review, 13(1), 15-38. https://doi.org/10.1017/mor.2016.53

Sanchis, T., Sanchis-Llopis, J. A., Esteve, V., \& Cubel, A. (2015). Total factor productivity, domestic knowledge accumulation, and international knowledge spillovers in the second half of the twentieth century. Cliometrica, 9(2), 209-233. https://doi.org/10.1007/s11698-014-0114-x

Sattar, A., \& Mahmood, T. (2011). Intellectual Property Rights and Economic Growth: Evidences from High, Middle and LowIncome Countries. Pakistan Economic and Social Review, 49(2), 163-186.

https://doi.org/10.1111/j.1465-7287.1997.tb00477.x

Thompson, M. A., \& Rushing, F. W. (1999). An Empirical Analysis of the Impact of Patent Protection on Economic Growth: An Extension. Journal of Economic Development, 24, 67-76. http://www.jed.or.kr/full-text/24-1/thompson.PDF

Van Zeebroeck, N. (2011). Long Live Patents: The Increasing Life Expectancy of Patent Applications and Its Determinants. Review of Economics and Institutions, 2(3), 1-37. https://doi.org/10.5202/rei.v2i3.41

World Bank (2019). World Development Indicators. Retrieved from https://datacatalog.worldbank.org/dataset/worlddevelopment-indicators

Xu, B., \& Chiang, E. P. (2005). Trade, Patents and International Technology Diffusion. Journal of International Trade and Economic Development, 14, 115-135. doi: https://doi.org/10.1080/0963819042000333270

Yun, J., Jeong, E., Lee, Y., \& Kim, K. (2018). The Effect of Open Innovation on Technology Value and Technology Transfer: A Comparative Analysis of the Automotive, Robotics, and Aviation Industries of Korea. Sustainability, 10(7), 2459. https://doi.org/10.3390/su10072459

\section{Appendix 1}

Distribution of countries studied by GDP per capita level

\begin{tabular}{|c|c|c|c|}
\hline Super-high income Countries & High-Income Countries & Upper-middle Income Countries & Lower-middle Income Countries \\
\hline Austria & Argentina & Belarus & Bangladesh \\
\hline Australia & Chile & Bosnia and Herzegovina & Egypt, Arab Rep. \\
\hline Belgium & Croatia & Brazil & Guatemala \\
\hline Finland & Czech Republic & Colombia & Indonesia \\
\hline France & Estonia & Ecuador & Moldova \\
\hline Germany & Greece & Jamaica & Pakistan \\
\hline Italy & Hungary & Jordan & Tunisia \\
\hline Japan & Latvia & Malaysia & Ukraine \\
\hline Korea, Rep. & Lithuania & Peru & Vietnam \\
\hline Norway & Portugal & Romania & \\
\hline Singapore & Slovak Republic & Russian Federation & \\
\hline Spain & Uruguay & Thailand & \\
\hline Sweden & & Turkey & \\
\hline Switzerland & & & \\
\hline United Kingdom & & & \\
\hline United States & & & \\
\hline
\end{tabular}

